\title{
Retrospective Analysis of Antibiotic Susceptibility Patterns of Respiratory Isolates of Pseudomonas Aeruginosa in a Chest Diseases Public Hospital
}

\author{
Abdullah Şimşek ${ }^{1}$ İlhami Yapıc1 ${ }^{1}$,Ekrem Temiz ${ }^{2}$, İbrahim Ocak ${ }^{1}$, Mustafa Kolsuz ${ }^{1}$ \\ ${ }^{1}$ Department of Chest Diseases, Prof. Dr. Türkan Akyol Chest Diseases Hospital, Bursa, Turkey \\ ${ }^{2}$ Department of Infectious Diseases and Clinical Microbiology, Prof. Dr. Türkan Akyol Chest Diseases Hospital, Bursa, Turkey
}

\begin{abstract}
Objective: Multidrug resistance is a major problem of Pseudomonas aeruginosa strains. We aimed to determine the level of resistance to the antipseudomonal antibiotics, the change in the rates of antibiotic resistance over the years, and mortality rate during hospital stay.
\end{abstract}

Methods: The microbiology database of P. aeruginosa isolated from 3708 sputum and 485 bronchial lavage samples at Chest Diseases Public Hospital from January 2009 to December 2013 was retrospectively reviewed. Imipenem, amikacin, tobramycin, ciprofloxacin, piperacillin, piperacillin/tazobactam ceftazidime, and cefepime resistance rates of $P$. aeruginosa strains were determined. Antimicrobial susceptibility was determined by the disk diffusion method, according to the Clinical Laboratory Standards Institute (CLSI) guidelines. P. aeruginosa was defined as resistant (resistance to at least one of the antipseudomonal antibiotics), and multidrug resistant (MDR) (resistance to three or more drugs of following classes: $\beta$-lactam, carbapenem, aminoglycoside, and fluoroquinolone).

Results: Five hundred and five P. aeruginosa isolates were tested. The antibiotic resistance rates were as follows; cefepime (26.7\%), ceftazidime (23.2\%), piperacillin (22.2\%), imipenem (21.8\%), piperacillin/tazobactam (19.2\%), ciprofloxacin (17.4\%), tobramycin (11.9\%), and amikacin (7.3\%). When compared 2009 and 2013, statistically significant reduction was observed in resistance rates to ciprofloxacin, amikacin, and cefepime antibiotics. Among 505 strains, 12.1\% were designated as being MDR. Out of 505 patients investigated, 34 (6.7\%) died during the hospital stay.

Conclusion: The clinical significance of these findings is important in the selection of appropriate empirical treatment of serious P. aeruginosa infections.

Keywords: Antibiotic resistance, multidrug resistance, P. aeruginosa

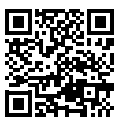

Received Date: 04.07.2015 Accepted Date: 23.01.2016 Available Online Date: 14.03.2016

DOI: 10.5152/ejp.2016.41636

Corresponding Author

Abdullah Şimşek

E-mail: abdullahsimsek1@yahoo.com.tr

-Available online at www.eurasianjpulmonol.com

\section{INTRODUCTION}

Pseudomonas aeruginosa is a bacterium that easily colonizes in the hospital environment. Thus, it causes nosocomial infections. This bacterium, which is an important opportunistic pathogen, is responsible for $10 \%-15 \%$ of nosocomial infections worldwide, and it is ranked as the $5^{\text {th }}$ most common nosocomial infection $(1,2)$.

Multidrug resistance (MDR) is a major problem of $P$. aeruginosa strains. The development of MDR during treatment creates difficulties in the treatment of the infection (2). MDR is defined as Pseudomonas infection that is resistant to at least three antibiotics from the groups of $\beta$-lactam, carbapenem, aminoglycoside, and fluoroquinolone (3). In hospital-acquired pseudomonal pneumonia, mortality was reported to be around $70 \%$ in some studies (4).

This study aimed to determine the antibiotic resistance rates of $P$. aeruginosa strains isolated from sputum and bronchial lavage samples that were sent to the microbiology laboratory of Chest Diseases Hospital between January 2009 and December 2013, the distribution of these rates over the years, and the mortality rate during hospitalization of patients with Pseudomonas infection. 


\section{METHODS}

In this study, 505 P. aeruginosa strains isolated from 485 bronchial lavage and 3708 sputum samples that were sent to the microbiology laboratory for culture antibiogram between January 1, 2009 and December 31, 2013 were evaluated retrospectively. Ethical approval for this study was received from the Clinical Research Ethics Committee of Bursa High Speciality Training and Research Hospital (Decision No: 2011-KAEK-25 2015/19-05). Because recordings were retrospectively evaluated, written informed consent was not obtained from patients.

Strains were defined using conventional diagnostic methods and Api 20 NE (Bio-Merieux, France) system. Antibiotic susceptibility was investigated through the Kirby-Bauer disc diffusion method using Mueller-Hinton agar in accordance with the criteria of "Clinical and Laboratory Standards Institute" (CLSI) (5). Susceptibilities to imipenem (IMP), amikacin (AK), tobramycin (TOB), ciprofloxacin (CIP), piperacillin (PIP), PIP/tazobactam (P/T), ceftazidime (CAZ), and cefepime (FEP) were evaluated in the isolated strains. The mortality rates during hospitalization were detected for patients with $P$. aeruginosa. While calculating the rates of antibiotic susceptibility, moderately susceptible strains were also accepted as resistant. Pseudomonas strains were defined as resistant in the presence of resistance to at least one of the anti-pseudomonas antibiotics and as multidrug resistant (MDR) in the presence of resistance to three or more drugs from the groups of $\beta$-lactam, carbapenem, aminoglycoside, and fluoroquinolone antibiotics.

\section{Statistical Analysis}

In the study, Chi-square analysis was used for evaluating the differences between the rates of resistant strains in 2009 and 2013 for eight different antibiotics. The results were evaluated by considering 95\% confidence level.

\section{RESULTS}

$P$. aeruginosa strains were found in 505 patients admitted between 2009 and 2013. Of these patients, 401 (79.4\%) were male and 104 (20.6\%) were female. The mean age of patients was $65 \pm 12.4$ years. $P$. aeruginosa was isolated from sputum in 477 cases (94.5\%) and from bronchial lavage in 28 cases (5.5\%). Although the number of patients with $P$. aeruginosa was 44 in 2009, it increased up to 185 in 2013 (Table 1).

With respect to the diagnoses of diseases, P. aeruginosa was reproduced in chronic obstructive pulmonary disease, bronchiectasis, and bronchogenic carcinoma more frequently (Table 2 ).

The study revealed that the antibiotics to which $P$. aeruginosa strains were mostly resistant were FEP (26.7\%) and CAZ (23.2\%). On the other hand, the lowest resistance rates were AK (7.3\%) and TOB (11.9\%) (while calculating the resistance rates, moderately susceptible strains were also accepted to be resistant) (Table 3).

The distributions of the rates of resistance to anti-pseudomonal antibiotics over the years are shown in Table 4. In the evaluation of differences between resistant strains in 2009 and 2013 through chisquare analysis, no statistically significant difference was observed between resistance rates in 2009 and 2013 for IMP, TOB, PIP, P/T, and CAZ antibiotics ( $p>0.05)$. On the other hand, there was a statistically significant difference for the CIP, AK, and FEP antibiotics $(p<0.01)$. The resistance rates for CIP, AK, and FEP were found to be significantly

\begin{tabular}{|l|l|}
\hline \multicolumn{2}{|c|}{ Table 1. Distribution of patient numbers according to years } \\
\hline Year & Number of patients \\
\hline 2009 & 44 \\
2010 & 62 \\
2011 & 91 \\
2012 & 123 \\
2013 & 185 \\
\hline Total & 505 \\
\hline
\end{tabular}

\begin{tabular}{|c|c|c|}
\hline & Frequency & $\%$ \\
\hline COPD & 348 & 68.9 \\
\hline Bronchiectasis & 87 & 17.2 \\
\hline Bronchogenic carcinoma & 25 & 5.0 \\
\hline Pneumonia & 17 & 3.4 \\
\hline Asthma & 13 & 2.6 \\
\hline Interstitial lung disease & 6 & 1.2 \\
\hline Tuberculosis & 6 & 1.2 \\
\hline Abscess & 2 & 0.4 \\
\hline Hemoptysis & 1 & 0.2 \\
\hline Total & 505 & 100 \\
\hline
\end{tabular}

higher in 2009 than those in 2013. In other words, a decline was observed in the resistance rates of CIP, AK, and FEP over the years. In our study, although no antibiotic resistance was detected in $53.5 \%$ of $P$. aeruginosa strains, $23.6 \%$ displayed resistance to three or more antibiotics (Table 5).

Although the rate of $P$. aeruginosa strain resistance to only one antibiotic group from $\beta$-lactam, carbapenem, aminoglycoside, and fluoroquinolone was $19.2 \%$, the rate of $P$. aeruginosa strain resistance to all of these four antibiotic groups was $4 \%$ (Table 6).

It was observed that the MDR strain rate, which was $18.2 \%$ in 2009 , decreased to $12.4 \%$ in 2013 (Table 7).

The mortality rate that developed during hospital stay in P. aeruginosa-isolated patients was found to be $6.7 \%$ (34 patients).

\section{DISCUSSION}

$P$. aeruginosa is a gram-negative, aerobic rod-shaped bacterium belonging to the family Pseudomonadaceae.

In $P$. aeruginosa strains, MDR is an important issue, and only a few antibiotics were found to be effective against $P$. aeruginosa (6). The bacterium has a resistance mechanism combined with a low intrinsic 


\begin{tabular}{|c|c|c|c|}
\hline Antibiotic & Result & Number & $\%$ \\
\hline \multirow{3}{*}{ Imipenem } & Susceptible & 395 & 78.2 \\
\hline & Moderately susceptible & 25 & 5 \\
\hline & Resistant & 85 & 16.8 \\
\hline \multirow{3}{*}{ Ciprofloxacin } & Susceptible & 417 & 82.6 \\
\hline & Moderately susceptible & 26 & 5.1 \\
\hline & Resistant & 62 & 12.3 \\
\hline \multirow{3}{*}{ Amikacin } & Susceptible & 468 & 92.7 \\
\hline & Moderately susceptible & 9 & 1.8 \\
\hline & Resistant & 28 & 5.5 \\
\hline \multirow{3}{*}{ Tobramycin } & Susceptible & 445 & 88.1 \\
\hline & Moderately susceptible & 13 & 2.6 \\
\hline & Resistant & 47 & 9.3 \\
\hline \multirow{3}{*}{ Piperacillin } & Susceptible & 393 & 77.8 \\
\hline & Moderately susceptible & 4 & 0.8 \\
\hline & Resistant & 108 & 21.4 \\
\hline \multirow{3}{*}{ Piperacillin/tazobactam } & Susceptible & 408 & 80.8 \\
\hline & Moderately susceptible & 6 & 1.2 \\
\hline & Resistant & 91 & 18 \\
\hline \multirow{3}{*}{ Cefepime } & Susceptible & 370 & 73.3 \\
\hline & Moderately susceptible & 54 & 10.7 \\
\hline & Resistant & 81 & 16 \\
\hline \multirow{3}{*}{ Ceftazidime } & Susceptible & 378 & 76.8 \\
\hline & Moderately susceptible & 18 & 3.6 \\
\hline & Resistant & 99 & 19.6 \\
\hline
\end{tabular}

Table 4. Distribution of resistance rates for anti-pseudomonal antibiotics according to years

\begin{tabular}{l|l|l|l|l|l|l|l|l|l|}
\hline & $\begin{array}{l}\text { Total } \\
\text { number } \\
\text { of strains }\end{array}$ & IMP & CIP & AK & TOB & PIP & P/T & FEP & CAZ \\
\hline 2009 & 44 & 13.6 & 29.5 & 18.2 & 18.2 & 11.4 & 6.8 & 43.2 & 29.5 \\
2010 & 62 & 24.2 & 17.7 & 4.8 & 3.2 & 11.3 & 113 & 29 & 22.6 \\
2011 & 91 & 16.5 & 28.5 & 13.2 & 13.2 & 31.8 & 27.5 & 39.5 & 32.9 \\
2012 & 123 & 19.5 & 14.6 & 5.7 & 8.9 & 30.9 & 23.5 & 20.3 & 21.1 \\
2013 & 185 & 27 & 10.8 & 3.7 & 14.6 & 17.8 & 17.8 & 20 & 18.4 \\
Total & 505 & 21.8 & 17.4 & 7.3 & 11.9 & 22.2 & 19.2 & 26.7 & 23.2 \\
AK: Amikacin; CAZ: ceftazidime; CIP: ciprofloxacin; FEP: cefepime; IMP: imipenem; PIP: piperacillin; P/T: piperacillin/tazobactam; TOB: tobramycin \\
\hline
\end{tabular}


Table 5. The numbers and percentages of antibiotics to which $P$. aeruginosa strains are resistant

\begin{tabular}{|l|l|l|}
\hline Number of resistant antibiotics & $\begin{array}{l}\text { Number } \\
\text { of patients }\end{array}$ & $(\%)$ \\
\hline 0 & 270 & $(53.5)$ \\
1 & 67 & $(13.3)$ \\
2 & 49 & $(9.7)$ \\
$\geq 3$ & 119 & $(23.6)$ \\
\hline Total & 505 & \\
\hline
\end{tabular}

Table 6. The numbers and percentages of antibiotic groups to which $P$. aeruginosa strains are resistant

\begin{tabular}{|l|l|l|}
\hline Number of resistant antibiotics & $\begin{array}{l}\text { Number of } \\
\text { patients }\end{array}$ & $(\%)$ \\
\hline 0 & 270 & $(53.5)$ \\
1 & 97 & $(19.2)$ \\
2 & 77 & $(15.2)$ \\
\hline 3 & 41 & $(8.1)$ \\
4 & 20 & $(4)$ \\
\hline Total & 505 & \\
\hline
\end{tabular}

Table 7. MDR P. aeruginosa strain rates according to years

\begin{tabular}{|l|l|l|l|}
\hline & $\begin{array}{l}\text { Number of } \\
\text { strains }\end{array}$ & $\begin{array}{l}\text { Number of } \\
\text { MDR strains }\end{array}$ & $\begin{array}{l}\text { Percentage } \\
\text { of MDR } \\
\text { strains (\%) }\end{array}$ \\
\hline 2009 & 44 & 8 & 18.2 \\
2010 & 62 & 7 & 11.3 \\
2011 & 91 & 12 & 13.2 \\
2012 & 123 & 11 & 8.9 \\
2013 & 185 & 23 & 12.4 \\
\hline Total & 505 & 61 & 12.1 \\
\hline MDR: Multidrug resistance & \multicolumn{2}{|l}{}
\end{tabular}

outer membrane permeability, formation of cephalosporinase, and presence of an efflux pump. As a result, when MDR Pseudomonas infections occur with wrong drug use, they create serious problems in nosocomial infections (7).

The definition of MDR Pseudomonas infection differs. Although resistance to a single antibiotic group is defined as MDR in some studies, resistance to all tested antibiotics is accepted as MDR in other studies (8). According to the generally accepted view, MDR is defined as resistance to at least three antibiotics from the groups of $\beta$-lactam, carbapenem, aminoglycoside, and fluoroquinolone (3).
In some studies, mortality was reported to be around 70\% in hospital-acquired pseudomonal pneumonia (4). This high rate of mortality was found to be associated with a high resistance pattern of $P$. aeruginosa (9).

The mean age of patients included in the study was high $(65 \pm 12.4$ years), and most of them were male (79.4\%). It was observed that the number of patients with $P$. aeruginosa infection increased over the years (Table 1). This increase was attributed to increasing patients and materials collected from these patients for evaluation.

The most commonly diagnosed diseases were chronic obstructive pulmonary disease (68.9\%) and bronchiectasis (17.2\%) (Table 2). The finding of Pseudomonas infection in patients with bronchial carcinoma and tuberculosis was evaluated to be striking.

In this study, it was detected that $P$. aeruginosa strains were less resistant to AK (7.3\%) and TOB (11.9\%), and they were more resistant to FEP (26.7\%) and CAZ (23.2\%) (Table 3).

Carbapenems are among the broadest spectrum $\beta$-lactam antibiotics, and development of resistance to these antibiotics has been observed recently (10). In this study, IMP resistance was found to be $21.8 \%$. IMP resistance is reported to vary between $16.8 \%$ and $54 \%$ in studies conducted in Turkey (11-21) and between $7 \%$ and $37.4 \%$ in foreign studies $(22,27)$. High resistance rates were detected in studies on intensive care patients (Table 8). As is seen in our study, the rate of IMP resistance is consistent with the studies conducted in Turkey but relatively higher than the studies conducted in other countries.

For AK from aminoglycosides, resistance develops more rarely than for other members of the group because AK is less affected by aminoglycoside-modifying enzymes (28). In our study, the AK resistance rate was found to be $7.3 \%$. The AK resistance rate is seen to vary between 4\% and 38\% in Turkish studies and between 3.3\% and 38.8\% in foreign studies (Table 8). According to these results, it can be said that AK resistance is low in Turkey and other countries at similar rates.

In our study, the CIP resistance rate was detected as $17.4 \%$. This rate is similar to CIP resistance rates found in Turkey and other countries (Table 8).

TOB resistance was found to be $11.9 \%$. TOB resistance was detected between $4.5 \%$ and $58.4 \%$ in the studies performed in Turkey and other countries (Table 8 ).

In this study, the PIP resistance rate was found to be $22.2 \%$. It was demonstrated in Turkish and foreign studies that this resistance was at different rates varying from $10.8 \%$ to $58 \%$ (Table 8 ).

The resistance rate for FEP was detected to be $26.7 \%$. Similar to our study, these rates are generally high in Turkey and other countries (Table 8).

The CAZ resistance rate was $23.2 \%$. Considering Table 8 , it can be said that CAZ resistance rates are very variable in Turkey and other countries.

Although an increase was observed in the rates of IMP, PIP, and P/T resistance over the years, no statistically significant difference was 


\begin{tabular}{|l|l|l|l|l|l|l|l|}
\hline \multicolumn{8}{|c|}{ Table 8. Antibiotic resistance rates (\%) detected in P.aeruginosa strains in some studies that were conducted in Turkey and other countries } \\
\hline Study & IMP & AK & CIP & TOB & PIP & FEP & CAZ \\
\hline Göktaş et al. (11) & 27.2 & 18.2 & 31.8 & - & - & 59 & 31.8 \\
\hline Ertürk et al. (12) & 21 & 38 & 53 & - & - & 66 & 17 \\
\hline Alaşehir et al. (13) & 23.8 & 9.8 & 19.7 & - & 23 & 24.6 & 23.8 \\
\hline Öztürk et al. (14) & 23 & 4 & 14 & - & 28 & 87 & 30 \\
\hline Aktepe et al. (15) & 16.8 & 4.9 & 33.3 & 4.9 & - & 74.8 & 69.9 \\
\hline Gazi et al. (16) & 34.3 & 13.1 & 23.4 & - & 31.5 & - & 25.9 \\
\hline Gönlügür et al. (17) & 21.6 & 25.4 & 16.1 & 58.4 & 21.8 & - & 50.8 \\
\hline Ekşi et al. (18) & 18 & - & 20 & - & 22 & 24 & 27 \\
\hline Üstün (19) & - & 31 & 35 & - & 58 & 49.8 & 55 \\
\hline Özdemir et al. (20) & 54 & 24 & 44 & - & - & 43 & 36 \\
\hline Ersöz et al. (21) & 29 & 32 & 9 & 44 & 32 & 21 & 38 \\
\hline Lin et al. (22) & 10.2 & - & - & - & - & - & - \\
\hline Al-Jasser et al. (23) & 9.8 & 14.2 & 7.8 & - & - & - & 18.2 \\
\hline Guerrero et al. (24) & 7 & 3.2 & 21.7 & 4.5 & - & - & 10 \\
\hline Raja and Singh (25) & 9.9 & 6.73 & 11.3 & - & 10.8 & - & 10.9 \\
\hline Van Eldere (26) & 9.5 & 10.5 & 24 & 19.5 & 24 & 29.5 & 28.5 \\
\hline Pinheiro (27) & 37.4 & 38.8 & 52 & - & - & 60.4 & 56.6 \\
\hline This study & 21.8 & 7.3 & 17.4 & 11.9 & 22.2 & 26.7 & 23.2 \\
\hline AK: Amikacin; CAZ: ceftazidime; CIP: ciprofloxacin; FEP: cefepime; IMP: imipenem; PIP: piperacillin; TOB: tobramycin & & \\
\hline
\end{tabular}

found among the resistance rates of IMP, TOB, PIP, P/T, and CAZ between the years of 2009 and 2013. The presence of a statistically significant difference in the resistance rates of CIP, AK, and FEP is a considerable finding. It is thought that this decrease was associated with the fact that the use of these antibiotics for lung infection due to Pseudomonas was low in our hospital.

As is seen in Table 5, 53.5\% of strains are susceptible to all antibiotics. It is striking that the number of strains resistant to three or more antibiotics is higher than the number of strains resistant to one or two antibiotics. In other words, when a resistant strain develops, the possibility for this strain to be resistant to three or more drugs is higher.

In this study, it was observed that resistance mosty developed to a single antibiotic group (19.2\%). The rate of strains resistant to three or more antibiotics, namely MDR strains, was $12.1 \%$ (61 patients) (Table 6,7$)$. The rate of strains resistant to all antibiotic groups was $4 \%$ (resistant to all four groups). The rate of MDR strains was reported as $6.4 \%$ in the study of Al-Jasser and Elkhizzi (23) from Saudi Arabia, $5.7 \%$ by Raja and Singh (25) from Malaysia, $9.8 \%$ by Gailiene et al. (29) from Lithuania, and $3.3 \%$ by Yoshimura et al. (30) from Japan. It can be said that the MDR strain rate in our study is higher than that in other countries. Moreover, it was observed that the MDR strain rate, which was $18.2 \%$ in 2009 , decreased to $12.4 \%$ in 2013 (Table 7).
In our study, the rate of mortality that occurred during hospitalization in patients with isolated P. aeruginosa was found to be $6.7 \%$ (34 patients). This rate was reported as $51.1 \%$ in the study of Pinheiro et al. (27) and $25.2 \%$ in the study of Joo et al. (31). The reason for lower mortality in our study than in other studies is that those studies were conducted among intensive care patients or patients with bacteremia.

\section{CONCLUSION}

The antibiotics to which $P$. aeruginosa strains are more susceptible are $A K$ and $T O B$, and the antibiotics to which these strains are more resistant are FEP and CAZ. The resistance rates for $C I P, A K$, and FEP antibiotics decline over the years. Because the IMP resistance rates in Turkey were observed to increase gradually over the years and they were found to be higher than in other countries (although it was not statistically significant), it is suggested that the use of IMP in the treatment of $P$. aeruginosa infection should be reduced. The FEP resistance rates are generally high in our study and also in Turkey and other countries. However, it is pleasing that this resistance rate decreased over the years. While using empirical antibiotics in the treatment of $P$. aeruginosa, it should be kept in mind that the FEP, $C A Z$, and IMP resistance rates are high. Because approximately half of the strains display at least one antibiotic resistance, it is suggested that the use of at least two antibiotics in a treatment will be more 
accurate. In our study, the mortality rate that developed during hospitalization of patients with $P$. aeruginosa infection was low. The rates of MDR P. aeruginosa decrease over the years but are higher in Turkey than in other countries.

Ethics Committee Approval: Ethics committee approval was received for this study from the ethics committee of Bursa Yüksek Ihtisas Training and Research Hospital as a decision number 2011-KAEK-25 2015/19-05.

Informed Consent: In this study, the microbiology database of isolated $P$. aeruginosa was retrospectively reviewed. So written/verbal informed consent was not obtained from patents who participated in this study.

Peer-review: Externally peer-reviewed.

Author Contributions: Concept - A.Ş.; Design - A.Ş., I.Y.; Supervision - E.T., I.O.; Materials - A.Ş., M.K.; Data Collection and/or Processing - I.Y., E.T.; Analysis and/ or Interpretation - A.Ş., E.T.; Literature Search - A.Ş., E.T.; Writing Manuscript A.Ş.; Critical Review - E.T., I.Y.

Conflict of Interest: No conflict of interest was declared by the authors.

Financial Disclosure: The authors declared that this study has received no financial support.

\section{REFERENCES}

1. Blanc DS, Petignat C, Janin B, Bille J, Francioli P. Frequency and molecular diversity of Pseudomonas aeruginosa upon admission and during hospitalization: a prospective epidemiologic study. Clin Microbiol Infect 1998; 4: 242-7. [CrossRef]

2. Pier GB, Ramphal R. Pseudomonas aeruginosa. In: Mandell GL, Bennet $\mathrm{JE}$, Dolin R, editors. Mandell, Douglas and Bennett's principles and practice of infectious diseases. 6nd ed. Philadelphia: Elsevier Churchill Livingstone; 2005; 2: 587-615.

3. Obritsch MD, Fish DN, MacLaren R, Jung R. Nosocomial infections due to multidrug-resistant Pseudomonas aeruginosa: Epidemiology and treatment options. Pharmacotherapy 2005; 25: 1353-64. [CrossRef]

4. Chastre J, Trouillet JL. Problem pathogens (Pseudomonas aeruginosa and Acinetobacter). Semin Respir Infect 2000; 15: 287-98. [CrossRef]

5. Natonal Committee for Clinical Laboratory Standarts (2000): Methods for dilution antimicrobial susceptibility tests for bacteria that grow aerobically. 5nd ed. Approved standards M7-A4. Nationa Committee for Clinical Laboratory Standards, Wayne, Pa.

6. Carmeli Y, Troillet N, Eliopoulos GM, Samore MH. Emergence of antibioticresistant pseudomonas aeruginosa: comparison of risks associated with different anti pseudomonal agents. Antimicrob Agents Chemother 1999; 43: 1379-82.

7. Vahapoğlu H, Akhan SÇ.Pseudomanas aeruginosa ve diğer Pseudomonas türleri, "Wilke Topçu A, Söyletir G, Doğanay M editörler. Enfeksiyon Hastalıkları ve Mikrobiyolojisi, Cilt 2, Etkenlere Göre Enfeksiyonlar, 3. baskı" kitabında s. 2175-86, Nobel Tıp Kitabevleri, İstanbul, 2008.

8. Falagas ME, Koletsi PK, Bliziotis IA. The diversity of definitions of multidrugresistant (MDR) and pandrug-resistant (PDR) Acinetobacter baumannii and Pseudomonas aeruginosa. J Med Microbiol 2006; 55: 1619-29. [CrossRef]

9. Samporn S, Chuntima T, Thitiya $Y$, Chertask D. Prevalence and antimicrobial susceptibility of pseudomonas aeruginosa mucoid and non-mucoid type. Southeast Asian J Trop Med Public Health 2004; 35: 893-94.

10. Livermore DM. The impact of carbapenemases on antimicrobial development and therapy. Curr Opin Invest Drugs 2002; 3: 218-24.

11. Göktaş U, Yaman G, Karahocagil MK, Bilici A, Katı I, Berktaş M. Akdeniz anestezi yoğun bakım ünitesinde hastane enfeksiyonu etkenleri ve direnç profilinin değerlendirilmesi. Türk Yoğun Bakım Derneği Derg 2010; 8: 13-7.
12. Ertürk A, Çiçek AÇ, Köksal E, Köksal ZŞ, Özyurt S. Yoğun bakim ünitesinde yatan hastaların çeşitli klinik örneklerinden izole edilen mikroorganizmalar ve antibiyotik duyarlılıkları. ANKEM Derg 2012; 26: 1-9.

13. Alaşaehir EA, Karadeniz A, Balıkçı A, Eren TA. Klinik örneklerinden izole edilen Pseudomonas aeruginosa suşlarının antibiyotik duyarlııkları. Maltepe Tip Dergisi 2013; 5: 12-6.

14. Öztürk CE, Albayrak HT, Altınöz A, Ankaralı H. Pseudomonas aeruginosa suşlarında antibitotiklere direnç ve beta-Laktamaz oranları. ANKEM Derg 2010; 24: 117-23.

15. Aktepe OC, Aşık G, Çetinkaya Z, Çiftçi IH, Altındiş M. Klinik örneklerden izole edilen pseudomonas aeruginosa suşlarında antibiyotik direnci. Türk Mikrobiyol Cem Derg 2010; 40: 225-31.

16. Gazi H, Kurutepe $S$, Sürücüoğlu $S$, Kan EÜ, Özbakkaloğlu B. Hastane kökenli pseudomonas aeruginosa suşlarında antimikrobiyal direnç. Hastane Infeksiyon Derg 2004; 8: 299-303.

17. Gonlugur U, Bakici MZ, Ozdemir L, Akkurt I, İçağasıoğlu S, Gültekin F. Retrospective analysis of antibiotic susceptibility patterns of respiratory isolates of Pseudomonas aeruginosa in a Turkish University Hospital. Ann Clin Microbiol Antimicrob 2003; 2: 5. [CrossRef]

18. Ekși F, Bayram A, Balcı İ, Özer G. Pseudomonas aeruginosa suşlarında indüklenebilir beta-laktamaz aktivitesinin ve antibiyotiklere direncin araştırılması. Türk Mikrobiyol Cem Derg 2007; 37: 142-6.

19. Üstün C. Hastane kökenli karbapenem dirençli ve duyarlı Pseudomonas aeruginosa suşlarının çeşitli antibiyotiklere direnç oranları. ANKEM Derg 2010; $24: 1-6$

20. Özdemir M, Erayman I, Dağı HT, Baykan M, Baysal B. Hastane infeksiyonu etkeni Pseudomonas suşlarının antibiyotiklere duyarlılıkları. ANKEM Derg 2009; 23: 122-6.

21. Ersöz G, Otağ F, Bayındır I, Kandemir Ö, Aslan G, Kaya A. Nozokomiyal Pseudomonas aeruginosa izolatlarında antibiyotik direnci ve karbapenemlere dirençli suşlar için meropenemin MiK değerleri. ANKEM Derg 2004; 18: 28-31.

22. Lin KY, Lauderdale TL, Wang JT, Chang SC. Carbapenem-resistant Pseudomonas aeruginosa in Taiwan: Prevalence, risk factors, and impact on outcome of infections. J Microbiol Immunol Infect 2016; 49: 52-9. [CrossRef]

23. Al-Jasser AM, Elkhizzi NA. Antimicrobial susceptibility pattern of clinical isolates of Pseudomonas aeruginosa. Saudi Med J 2004; 25: 780-4.

24. Guerrero C, Cesteros R, Miranda A, Menasalvas A, Blazquez R, Segovia M. Antimicrobial susceptibility of Pseudomonas aeruginosa clinical isolates in Murcia, Spain. See comment in PubMed Commons belowRev Esp Quimioter 2003; 16: 444-9.

25. Raja NS, Singh NN. Antimicrobial susceptibility pattern of clinical isolates of Pseudomonas aeruginosa in a tertiary care hospital. J Microbiol Immunol Infect 2007; 40: 45-9.

26. Van Eldere J. Multicentre surveillance of Pseudomonas aeruginosa susceptibility patterns in nosocomial infections. J Antimicrob Chemother 2003; 51: 347-52. [CrossRef]

27. Pinheiro MR, Lacerda HR, Melo RG, Maciel A. Pseudomonas aeruginosa infections: factors relating to mortality with emphasis on resistance pattern andantimicrobial treatment. Braz J Infect Dis 2008; 12: 509-15. [CrossRef]

28. Güney M, Bedir O, Kılıç A, Başustaoğlu AC. GATA tıbbi mikrobiyoloj laboratuarında hemokültür örneklerinden izole edilen Pseudomonas aeruginosa suşlarının antibiyotik direnç durumları. Gülhane Tıp Derg 2011; 53: 119-22.

29. Gailiene G, Pavilonis A, Kareiviene V. The peculiarities of Pseudomonas aeruginosa resistance to antibiotics and prevalence of serogroups. See comment in PubMed Commons belowMedicina (Kaunas) 2007; 43: 36-42.

30. Yoshimura H, To H, Narita C, Tokushiqe C, Kakudo T, Otsubo C, et al. Antimicrobial susceptibility patterns of Pseudomonas aeruginosa isolated from 2006 to 2008 in Fukuoka University Hospital. Jpn J Antibiot 2009; 62: 502-8

31. Joo EJ, Kang Cl, Ha YE, Kang SJ, Park SY, Chung DR, et al. Risk factors for mortality in patients with Pseudomonas aeruginosa bacteremia: clinical impact of antimicrobial resistance on outcome. Microb Drug Resist 2011, 17: 305-12. [CrossRef] 